\title{
Results from Mexico's 2018 Report Card on Physical Activity for Children and Youth
}

\author{
Karla I. Galaviz, Gabriela Argumedo Garcia, Alejandro Gaytán-González, Inés González-Casanova, \\ Martín Francisco González Villalobos, Alejandra Jáuregui, Edtna Jáuregui Ulloa, \\ Catalina Medina, Yoali Selene Pacheco Miranda, Marcela Pérez Rodríguez, \\ Eugen Resendiz, Ricardo Alejandro Retano Pelayo, María del Pilar Rodríguez Martínez, \\ and Juan Ricardo Lopez y Taylor
}

\section{Introduction}

Physical activity levels among Mexican children and youth have been below recommended standards in the past six years. ${ }^{1}$ More than half of children and a third of youth do not reach the recommended 60 daily minutes of moderate-to-vigorous intensity physical activity (MVPA). ${ }^{2}$ This is concerning given that inadequate physical activity is a leading risk factor for non-comminucable diseases $^{3}$ and is responsible for a substantial economic burden worldwide. ${ }^{4}$ The purpose of this paper is to summarize the results of Mexico's 2018 Report Card. Using the best available evidence, Mexico's 2018 Report Card aims to provide a comprehensive evaluation of how the country is doing in terms of promoting physical activity among children and youth.

\section{Methods}

The development of Mexico's 2018 Report Card involved obtaining relevant physical activity information, comparing it against established benchmarks, and assigning grades across 10 indicators. These indicators are grouped into 4 categories: I) Daily Behaviors (Overall Physical Activity, Organized Sport and Physical Activity Participation, Active Play, Active Transportation, Sedentary Behaviors); II) Settings and Sources of Influence (Family and Peers, School, Community and Environment); III) Strategies and Investments (Government), and IV) Physical Fitness.

To grade each indicator, we reviewed several sources of information published from 2010 forward. The main sources of information were the National Health and Nutrition Survey (ENSANUT) 2016, ${ }^{1,2}$ reports from the National Commission on Physical Culture and Sports (CONADE), ${ }^{5}$ census data from the National Institute of Statistics and Geography (INEGI), ${ }^{6-8}$ reports from the Secretary of Education, ${ }^{9}$ and legislative documents (e.g. General Law on Physical Culture and Sports). ${ }^{10}$

This work was conducted by a team of researchers and public health practitioners from the academic, government, and healthcare sectors with expertise in all areas assessed in the Report Card.

\section{Results and Discussion}

Grades for the Mexico's 2018 Report Card are summarized in Table 1 and the front cover is presented in Figure 1.

Only 7 out of 10 indicators were graded. Grades indicate that Mexican children and youth are not meeting the recommendations for physical activity and sedentary behaviors. Sports participation and active transportation levels are better but still need improving. Schools are failing to provide adequate physical education to all children. Over half of communities lack adequate physical activity spaces while the majority of parents have safety concerns. While the

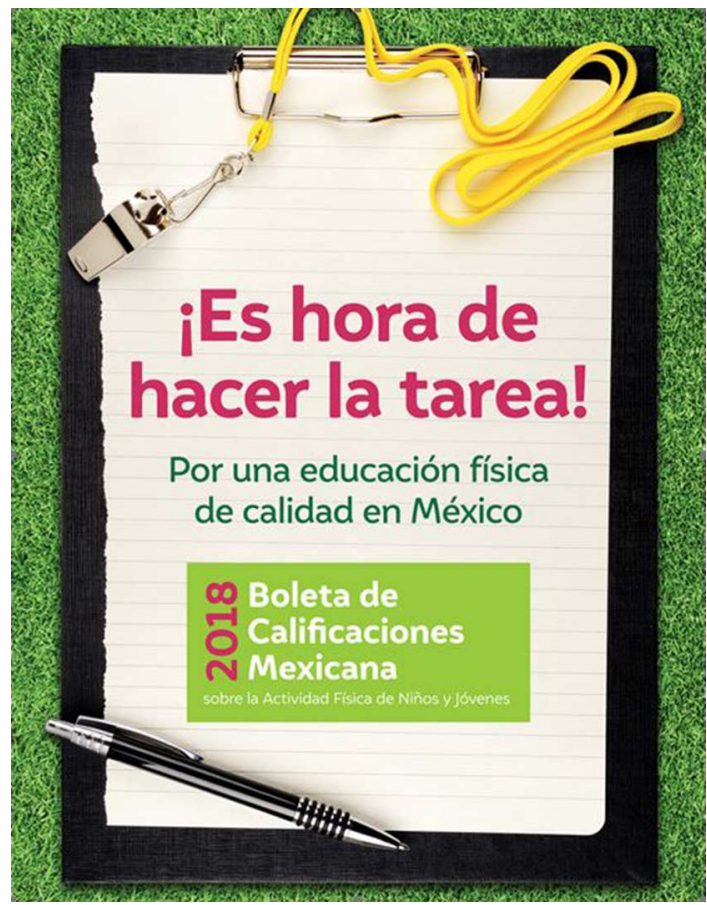

Figure 1 - Mexico's 2018 Report Card cover.

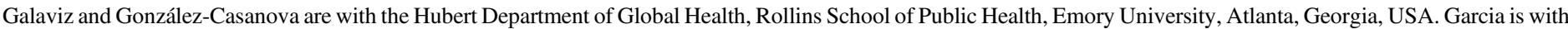

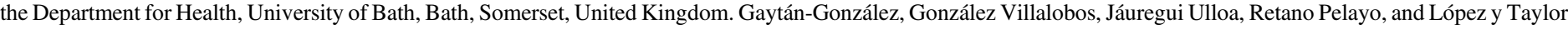

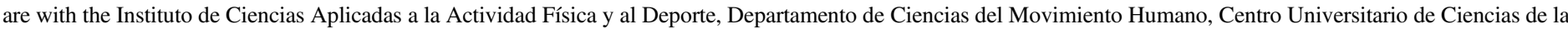

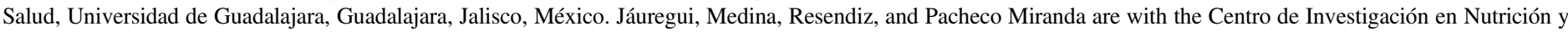

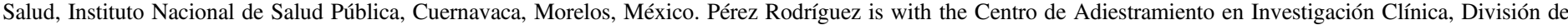

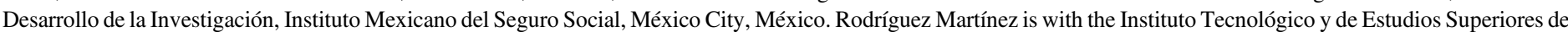
Occidente, Zapopan, Jalisco, México. Galaviz (kgalavi@emory.edu) is the corresponding author. 
Table 1 Grades and rationales for Mexico's 2018 Report Card

\begin{tabular}{|c|c|c|}
\hline Indicator & Grade & Rationale \\
\hline $\begin{array}{l}\text { Overall Physical } \\
\text { Activity }\end{array}$ & $\mathrm{D}+$ & $\begin{array}{l}\text { According to ENSANUT } 2016,{ }^{2} 60 \% \text { of youth } 15-19 \text { years old get at least } 60 \text { minutes of MVPA per day. Only } \\
17 \% \text { of children } 10-14 \text { years old get at least } 60 \text { minutes of MVPA per day. In this age group, less girls }(12.7 \%) \\
\text { than boys }(21.8 \%) \text { meet these recommendations. }\end{array}$ \\
\hline $\begin{array}{l}\text { Organized Sport } \\
\text { Participation }\end{array}$ & $\mathrm{C}$ & $\begin{array}{l}\text { According to ENSANUT } 2016,{ }^{1} 48.6 \% \text { of children } 10-14 \text { years of age participate in some type of organized } \\
\text { sport. }\end{array}$ \\
\hline Active Play & INC & There is insufficient data to grade this indicator. \\
\hline Active Transportation & $\mathrm{C}+$ & $\begin{array}{l}\text { According to INEGI } 2015 \text { census data, }{ }^{6} 54.8 \% \text { of children } 3 \text { years } \\
\text { and older walk to school and } 1.5 \% \text { ride bicycles. }\end{array}$ \\
\hline Sedentary Behavior & D- & $\begin{array}{l}\text { According to ENSANUT } 2016,{ }^{2} 22.7 \% \text { of } 10-14 \text { year old children spend no more than } 2 \text { hours per day in front of } \\
\text { a screen. Only } 21.4 \% \text { of } 15-19 \text { year-old youth spend no more than } 2 \text { hours per day in front of a screen. }\end{array}$ \\
\hline Physical Fitness & INC & There is insufficient data to grade this indicator. \\
\hline Family and Peers & INC & There is insufficient data to grade this indicator. \\
\hline School & $\mathrm{D}+$ & $\begin{array}{l}\text { According to the Secretary of Public Education }(2015),{ }^{9} \text { only } 36.3 \% \text { of school-age children in public schools } \\
\text { receive } 1 \text { hour of physical education per week. }\end{array}$ \\
\hline $\begin{array}{l}\text { Community and } \\
\text { Environment }\end{array}$ & $\mathrm{D}+$ & $\begin{array}{l}\text { INEGI census data show } 33 \% \text { of neighborhoods in Mexico have sidewalks and trees and that } 45 \% \text { have public } \\
\text { lighting. }{ }^{7} \text { INEGI data also show } 74 \% \text { of Mexican adults stopped allowing their children to go outside. }{ }^{8}\end{array}$ \\
\hline Government & $\mathrm{C}$ & $\begin{array}{l}\text { Two national physical activity programs (Ponte al } 100 \text { and Muevete en } 30 \text { ) signal interest in physical activity } \\
\text { promotion but their implementation and impact are unknown. Also, funds allocated for physical activity } \\
\text { promotion are insufficient ( } \$ 181 \text { million in } 2013 \text { and } \$ 202 \text { million Mexican pesos in 2014). }{ }^{5}\end{array}$ \\
\hline
\end{tabular}

current government administration introduced initiatives that signal commitment to promote physical activity, the degree to which these have been implemented and impacted physical activity is unknown.

We were unable to grade the Family and Peers, Active Play and Physical Fitness indicators due to lack of reliable national data. While data to grade most Daily Behaviors exist, these were selfreported and excluded children younger than 10 years of age.

\section{Conclusion}

Mexican children and youth are far from achieving the recommended levels of physical activity and screen time. In addition, schools, communities and government are not providing adequate physical activity opportunities. In light of the obesity and diabetes epidemic Mexico is facing, efforts should be directed towards promoting physical activity and combating sedentary behaviors. Findings from this Report Card can be used to guide this endeavour.

\section{References}

1. Medina C, Jáuregui A, Campos-Nonato I, Barquera S. Prevalencia y tendencias de actividad física en niños y adolescentes: resultados de la Ensanut 2012 y Ensanut MC 2016. Salud Publica de Mexico. 2018; 60:263-271.

2. Encuesta Nacional de Salud y Nutrición de Medio Camino. 2016. http:// promocion.salud.gob.mx/dgps/descargas1/doctos_2016/ensanut_mc_ 2016-310oct.pdf. Accessed May 21, 2018.
3. Lee IM, Shiroma EJ, Lobelo F, Puska P, Blair SN, Katzmarzyk PT. Effect of physical inactivity on major non-communicable diseases worldwide: an analysis of burden of disease and life expectancy. Lancet. 2012;280(9838):219-229.

4. Ding D, Lawson KD, Kolbe-Alexander TL, et al. The economic burden of physical inactivity: a global analysis of major noncommunicable diseases. Lancet. 2016;388(10051):1311-1324.

5. Gobierno de la República. Programa Nacional de Cultura Física y Deporte 2014-2018. Mexico. 2014. http://www.dof.gob.mx/nota detalle.php?codigo $=5342830 \&$ fecha $=30 / 04 / 2014$. Accessed June 1, 2018.

6. INEGI. Encuesta intercensal. 2015. http://www.inegi.org.mx/est/ contenidos/Proyectos/encuestas/hogares/especiales/ei2015/. Accessed May 24, 2018.

7. INEGI. Resultados sobre infraestructura y características del entorno urbano. 2010. http://www3.inegi.org.mx/sistemas/microdatos/ default_urbano.aspx. Accessed March 20, 2018.

8. Encuesta Nacional de Victimización y Percepción de Seguridad Pública (ENVIPE). 2017. http://www.beta.inegi.org.mx/proyectos/ enchogares/regulares/envipe/2017/. Accessed February 28, 2018.

9. Secretaria de Educacion Publica. Informe sectorial 1: Educación Física y Deporte en el Sistema Educativo. 2015. http://www.dgb.sep. gob.mx/acciones-y-programas/ESDM/Informes_Sectoriales/

1_Edu_Fisica_Deporte_universitario.pdf. Accessed May 20, 2018.

10. Gobierno de la República. Decreto por el que se expide la Ley General de Cultura Física y Deporte. Mexico. 2014. http://www. dof.gob.mx/nota_detalle.php?codigo $=5301698 \&$ fecha=07/06/2013. Accessed June 1, 2018. 